\title{
IMAGE ANALYSIS MEASUREMENTS AND THEIR CORRELATIONS WITH EGG QUALITY TRAITS AND EGG CHEMICAL COMPOSITION OF DIFFERENT EGG SHELL PATTERNS OF JAPANESE QUAIL
}

\author{
ABDELFATAH, M. HAMED , OMHASHEM Y. MAHFOZ, \\ H. A. ABDELATIF, H. A. H. ABD EL-HALIM and M. I. BADAWY \\ Anim. Prod. Res. Inst. Agric. Res. Center, Ministry of Agric., Dokki, Giza, Egypt. \\ Corresponding author: Mohamed Hamed Abdelfatah ; E-Mail: \\ mohamedashour8875@gmail
}

(Manuscript received 29 January 2018)

\begin{abstract}
$\mathrm{T}$ he present study was carried out to identify the effect of color and pattern varieties of Japanese quail egg shell on image analysis measurements for the egg shell, egg quality traits and chemical composition of whole egg components, as well as the correlations between image analysis measurements for egg shell with egg quality traits. Image analysis parameters of egg shell, egg quality traits, chemical composition for egg components were evaluated at 19 weeks of age for a total 744 Japanese quail eggs collected from 186 identified females classified by their egg shell imprints according to egg shell color and pattern into five groups of egg type [1 $1^{\text {st }}$ group: white egg shell (Non-pigmented), $2^{\text {nd }}$ group: grayish white egg shell pigmented with small black pigments spots (Black spotted), $3^{\text {rd }}$ group: small black pin dots on grayish brown shell back ground (Pin dotted), $4^{\text {th }}$ group: slightly blue pigments (Sandy gray), $5^{\text {th }}$ group: brown egg shell with heavily dark pigmentation (Heavily dark)]. There are significant differences $(P \leq 0.05)$ between studied egg shell patterns for image analysis measurements. Sandy gray eggs had significantly the highest values, while white egg had the lowest values for all studied external egg quality traits comparing with other egg groups. No significant influence of egg shell patterns on chemical composition analysis for egg components for different gropes except moisture and fat $\%$ in white eggs (71.3 and 9.7\% respectively) which were significantly lower compared to other egg shell groups. Significant correlations, whether positive or negative were found between image analysis measurements of egg shell and some egg quality traits for different studied groups which can be used in future studies.
\end{abstract}

Key words: Japanese quail, image analysis measurements, egg quality, chemical composition and correlations

\section{INTRODUCTION}

Japanese quail egg shells are characterized by a variety of color patterns, ranging from dark brown, blue and white to buff, each heavily mottled with black, brown and blue and varies from white to blue and green (Narahari et al., 1988). Additionally, quail eggs have brown or reddish-brown patterned areas on a light 
1096 IMAGE ANALYSIS MEASUREMENTS AND THEIR CORRELATIONS WITH EGG QUALITY TRAITS

AND EGG CHEMICAL COMPOSITION OF DIFFERENT EGG SHELL PATTERNS OF JAPANESE QUAIL

background (Sezer and Tekelioglu, 2009). Biliverdin, a green pigment, is a byproduct of hemoglobin breakdown and will eventually display a blue or green color in the egg shell. Protoporphyrines, in contrast to biliverdin, is an immediate precursor of the heme molecule, and will give egg shells a reddish or brown color (Mikšík et al. 1996). Yang and Wang. (2009) reported that shell thickness and shell weight can be accessed through intensity of the shell color. Farghly et al. (2015) reported that spotted brown eggs had significantly $(P \leq 0.05)$ thicker egg shell than those of spotted violet and white. This means that darker egg shell and yellow-brown egg shell eggs have a better egg shell breaking strength than the lighter ones. The brown-red egg shell pigment protoporphyrin was shown to be associated with shell thickness (Sanz and García-Navas, 2009), suggesting that protoporphyrin might have a structural function in strengthening the egg shell (Gosler et al., 2005). Significant differences in egg shell color characteristics between females indicated that quantification of egg shell color, using image analysis, could be used to assess egg shell color and pattern. The results of the discriminate function analysis demonstrated that the patterns on egg shells are important variables to describe egg shell pigmentation (Sezer and Tekelioglu, 2009). Egg quality is usually commented in connection with consumers' requirements and is performed by groups of methods, which give a general characteristics of eggs with intact egg shells (freshness, weight, size and shape, egg shell appearance) and the quality of egg parts (albumen, yolk and egg shell) as reported by Minvielle et al., 1997. Previous studies showed that there is a correlation between shell color and shell quality in eggs of a single strain. The correlation coefficient found between egg shell color and egg shell thickness was 0.37 . Furthermore, the measurement of shell color used in these studies is subjective and might be biased (Joseph et al., 1999). On the other hand, Sadjadi et al. (1983) found no significant differences between egg shell color and shell quality, shell thickness, albumen weight, yolk weight, or yolk cholesterol content. There is a widespread belief that pigmented eggs are stronger than white eggs (Yang et al., 2009). However, conflicting evidence has also been reported by Joseph et al. (1999).

There is still little evidence to show correlation between egg shell color and egg quality (Hsiu-Chou and Teng-Kuei, 2010). Therefore, the present study aimed to identify the effect of the pigmentations and patterns variety of Japanese quail egg shell on measurements of the image analysis for the egg shell, egg quality traits and the egg chemical composition. The correlations between the measurements of image analysis, for egg shell, with egg quality traits and chemical composition of the components of the egg will be evaluated. 


\section{MATERIALS AND METHODS}

The present study was carried out at Fayoum Poultry Research Station, Animal Production Research Institute, Agriculture Research Center.

Image analysis of egg shells, exterior and interior egg quality traits were evaluated at 19 weeks of age for a total 744 Japanese quail eggs collected from 186 identified females classified by their imprint egg shell according to egg shell color and pattern into five groups of egg types: $1^{\text {st }}$ group: white egg shell (nonpigmented), $2^{\text {nd }}$ group: grayish white egg shell pigmented with small black pigments spots (Black spotted), $3^{\text {rd }}$ group: small black pin dots on grayish brown shell back ground (Pin dotted), $4^{\text {th }}$ group: slightly blue pigments (sandy gray), $5^{\text {th }}$ group: brown egg shell with heavily dark pigmentation (Heavily dark) as shown in Figure (1). Former categories of egg shell patterns have been formed through mating of every female with a male produced from eggs that have the same pattern of the female over three successive generations. Inbreeding was avoided through no full or half sibs matings in each generation.

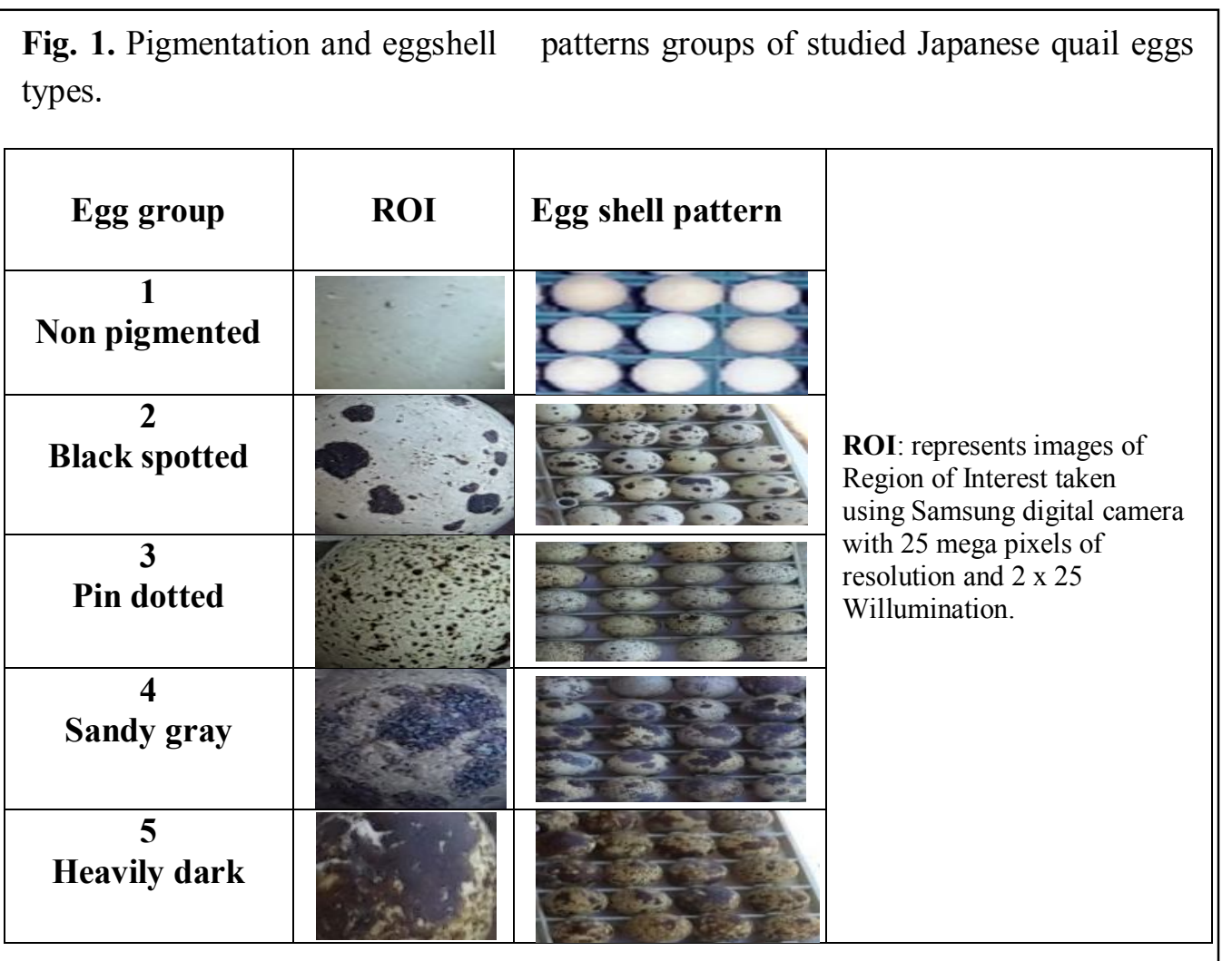

Birds were fed a layer diet (20\% crude protein, $2950 \mathrm{kcal} \mathrm{ME} / \mathrm{kg}$ and 2.5\% calcium) according to NRC (1994) recommendations and both feed and water were provided ad libitum throughout the experimental period. Artificial light was used 
1098 IMAGE ANALYSIS MEASUREMENTS AND THEIR CORRELATIONS WITH EGG QUALITY TRAITS

AND EGG CHEMICAL COMPOSITION OF DIFFERENT EGG SHELL PATTERNS OF JAPANESE QUAIL

beside the normal day light to provide 16-hour day photoperiod. Four sequential ovulated eggs from each hen were collected in an interval of one week. During $6 \mathrm{~h}$ of collection, each egg was photographed from one side, and then turned $180^{\circ}$ to the other side and photographed again to reduce the error arising from pattern distribution over the egg shell; images were taken $20 \mathrm{~cm}$ above the eggs using a digital camera (Samsung ${ }^{\circledR}$ with $3072 \times 2304$ pixels and 2563 colors).

A Delphi-based program was used to analyze the images for measurements of the image analysis for the egg shell. A rectangular area of two $\mathrm{cm}^{2}$ represent the majority of the examined egg was selected, because of the difference in size and shape of eggs. The program processes the region of interest (ROI) and calculates the mean values of intensity of the pixels in red, green and blue bands. This was done according to Viscarra et al. (2006). These red, green and blue (RGB) values were converted to Hue, Saturation and Lightness, (HSL) values using the procedure of. http://www.rapidtables.com/convert/color/rgb-to-hsl.htm.

Where, Hue $(H)$ : describes the dominant wave length of the color (measured in degrees, $\left.0^{\circ}-360^{\circ}\right)$, Saturation (S): is the amount of mixed $\mathrm{H}$ into the color (represented by the value from 0 to 100) and Lightness (L): the amount of light in the color and represented by the value from 0 to 100 where 0 corresponds to black and 100 to white (Hassan et al., 2014). The image analysis program can search inside image and select the pixels having similar color band intensities as a desired pixel. Then, selected pixels can be converted to a distinct color that is not represented in the egg shell (e.g. pure red: 255, 0, 0: R, G, B). Using this specification of the program, both of the total area of ROI and the colored patterns areas inside it are converted to counting pixels. Finally, pigmentation percentage, of each egg, is calculated as a proportion of counting pixels number into the colored patterns areas to the total number of pixels in the ROI according to Sezer and Tekelioglu (2009). After being photographed, egg weight was individually determined using an electronic scale with an accuracy of $0.1 \mathrm{~g}$. The length and width of the eggs were measured with a digital calliper to the nearest $0.01 \mathrm{~mm}$. After that the eggs were broken on a horizontal smooth surface, egg shells were washed with water and dried in order to clean the remaining albumen. Following this procedure, shell weights (with membranes) were measured using an electronic scale with an accuracy of $0.01 \mathrm{~g}$. Some external and internal quality traits (shell ratio, shape index, egg volume according to (Narushin, 1992), shell surface area (Paganelli et al. 1974), unit surface shell weight $\left(\mathrm{mg} / \mathrm{cm}^{2}\right)$, albumen weight, albumen ratio (\%), albumen index(\%), Internal quality unit (IQU) according to (Kondaiah et al., 1983), Haugh unit (HU), yolk ratio (\%), yolk index (\%) and yolk color) of the eggs were determined or 
estimated. Chemical composition of eggs interior components were determined as follows: Moisture content was determined by drying the whole egg contents at 100$102^{\circ} \mathrm{C}$ for $16-18 \mathrm{hrs}$ as described by AOCA (1990). Crude protein was estimated by multiplying 6.25 to nitrogen content obtained through semimicro-Kjeldahl method. Crude fat and ash were analyzed by Soxhlet extraction and $550^{\circ} \mathrm{C}$ muffle furnace, respectively. All the data of image analysis parameters and egg quality traits were analyzed using GLM procedures (SAS 9.1; 2003). The differences among means of different groups were separated by Duncan (1955) test at the level $5 \%$ of significance. Correlations between the studied traits were determined according to the PROC CORR procedure of the (SAS 9.1; 2003) statistical package by Pearson correlation coefficients by linear estimation.

\section{RESULTS AND DISCUSSION}

The descriptive statistics related to the image analysis measurements, external, internal egg quality traits and chemical composition of internal egg components for the five categories of egg shell patterns of Japanese quail eggs in the study are shown in Table 1. There are significant differences between studied egg shell patterns for image analysis measurements. White eggs had significantly $(P \leq 0.05)$ the highest values than red (171.6), green (155.3), blue (122.0), lightness $(58.0 \%)$ and hue (39.0). While the lowest values of those traits were observed for the heavily dark eggs (127.3, 94.6, 56.4, 36.0 and 32.4 respectively). On the contrary, heavily dark eggs had significantly the highest values of saturation \% $(38.9 \%)$ and pigmentation \% (69.3\%). The lowest values of saturation \% and pigmentation \% were found in the white egg group (23.3 and $6.2 \%$ respectively).

These results were in agreement with those observed by Duval et al. (2012), Nowaczewski et al. (2013), and Hassan et al. (2014).

Egg weight for sandy gray eggs were significantly $(P \leq 0.05)$ the heaviest followed by pin dotted, heavily dark and black spotted egg (12.4, 11.8, 11.3 and 11.2, respectively), while white egg had the lowest weight $(10.7 \mathrm{~g})$ as shown in Table 1.

No significant differences, in egg weights, were observed between sandy gray and pin dotted groups or between white, black spotted and heavily dark egg groups. Generally, egg weight was on the average $11.5 \mathrm{~g}$. This is consistent with those weights obtained by Oliveira et al. (2007) and Murakami et al. (2008).

Significant differences $(P \leq 0.05)$ for egg shape index were observed between white eggs (78.1) with the other groups. However, no significant differences were observed among black spotted (80.1), pin dotted (80.6), sandy gray (81.2) and heavily dark (81.1) groups for egg shape index (Table 1). 
Sandy gray egg had significantly the highest $(P \leq 0.05)$ egg volume, surface area and unit surface shell area weight $\left(11.4 \mathrm{~cm}^{3}, 25.5 \mathrm{~cm}^{2}\right.$ and $47.0 \mathrm{mg} / \mathrm{cm}^{2}$, respectively). This was followed by the pin dotted group $\left(10.86 \mathrm{~cm}^{3}, 24.86 \mathrm{~cm}^{2}\right.$ and $45.4 \mathrm{mg} / \mathrm{cm}^{2}$, respectively), while white egg had the lowest values $\left(9.9 \mathrm{~cm}^{3}, 23.29 \mathrm{~cm}^{2}\right.$ and $40.7 \mathrm{mg} / \mathrm{cm}^{2}$ for egg volume, surface area and unit surface shell weight, respectively) Table1.

Our results of egg surface area and unit surface shell area weight means were compatible to those reported by Kul and Seker (2004) and higher than that the reported values of egg surface area by Abu Tabeekh (2011). This might be due to his use of smaller eggs $(7.0 \mathrm{~g})$ than eggs in this study. This might had caused in egg surface area values in his study.

The highest significant $(P \leq 0.05)$ shell percentage values (Table 1$)$ were those of the sandy gray eggs (9.3\%). On the other hand the lowest shell percentages (Table 1$)$ were for the white eggs $(8.0 \%)$. Insignificant $(P>0.05)$ differences were found between sandy gray, black spotted and heavily dark egg groups and between white eggs and pin dotted eggs for shell percentages, as shown in Table 1.

Sandy gray eggs showed significantly $(P \leq 0.05)$ shell thickness $(24.0)$ than others eggs shells categories (Table 1 ). On the other hand, insignificant differences were found between white, black spotted, pin dotted and heavily dark eggs as presented in Table 1. The overall mean of egg shell thickness in the present study $(23.2 \mu \mathrm{m})$ was consistent with the finding cited by Hrncar et al. (2014). On the other hand the egg shell thickness of this study was some what higher than those reported by Orhan et al. (2001), they reported values from 19.0 to $22.0 \mu \mathrm{m}$.

Generally sandy gray eggs had significantly the highest values, while white eggs had the lowest values for all studied external egg quality traits as shown in Table 1. Odabaşi et al. (2007) indicated that egg size was the major factor affecting the color of the egg shell. These findings quantified the observations that hens which lay sandy gray eggs lay lighter colored eggs due to an increase in egg size associated with no proportionate change in the quantity of pigment deposited over the shell surface. This may be due to the increased stay period of the sandy gray egg in the oviduct which could improve the external egg quality

Information in Table 1 showed the effect of egg shell coloration on interior egg quality traits and chemical composition analysis for egg components for the different five studied categories of egg shell patterns. It was clearly noted that sandy gray eggs had significantly the highest values $(P \leq 0.05)$ for albumen $\%(55.0 \%)$ followed by white eggs $(53.8 \%)$ while the lowest albumen $\%$ was that of the heavily 
dark eggs (49.8\%). No significant differences for albumen \% were reported among the egg categories of white, black spotted, pin dotted and sandy gray egg groups.

No significant differences were found for albumen index between white, pin dotted and heavily dark egg groups or between black spotted and sandy gray egg categories, white eggs had the highest values for albumen index (11.1) while sandy gray eggs had the lowest albumen index (8.9) as shown in Table 1.

Heavily dark eggs had the highest Haugh units (88.6) while, the lowest value was that of sandy gray eggs (85.8). It was also noted that no significant differences were found in Haugh units between pin dotted and heavily dark egg groups or between white, black spotted and sandy gray eggs (Table 1 ).

As shown in Table 1, the highest internal quality unit (IQU) was found in pin dotted and heavily dark eggs ( 60.0 and 59.6, respectively). However, the lowest value was reported for the white eggs (53.3). No significant differences for (IQU) were noted between any of the other egg categories (Table 1).

The highest yolk color (6.0) was that of white eggs while the lowest color was that of the pin dotted eggs (4.6), as shown in Table 1. Insignificant differences were observed for yolk color between white, black spotted and sandy gray egg categories or between pin dotted, sandy gray and heavily dark egg groups (Table 1).

Heavily dark eggs had the highest yolk (41.4\%). The lowest percentage was observed in the sandy gray eggs (35.5\%) as shown in Table 1 . The only significant differences for yolk\% were between sandy gray eggs and heavily dark eggs. However, no significant differences for yolk \% were noted between sandy gray eggs with white, black spotted, pin dotted or between heavily dark eggs and the same groups. Results for yolk index (Table 1) showed that pin dotted egg had the highest yolk index value (45.1) while the lowest value was that of the white eggs (40.3) as shown in Table 1. Insignificant differences in yolk index were observed between black spotted, pin dotted, sandy gray and heavily dark egg categories.

Generally white eggs had significantly the highest $(P \leq 0.05)$ albumen index and yolk color and the lowest values for internal quality unit and yolk index. On the contrary, pin dotted eggs had the highest values for internal quality unit and yolk index.

Table 1 indicates the effect of egg shell coloration on the chemical composition of egg components. White eggs had significantly $(P \leq 0.05)$ the lowest moisture and fat content ( 71.3 and $9.7 \%$, respectively) in comparison with other egg shell groups. Insignificant differences were found $(P<0.05)$ for moisture and fat percentages between black spotted, pin dotted, sandy gray and heavily dark eggs. 
No significant differences were observed in protein or ash percentages between all studied groups (Table 1 ).

In general, results of means values for shell thickness and yolk ratios were similar to the findings of Abu Tabeekh (2011). However, they differ in other traits such as egg weight and Haugh unit. On the other hand, these results were not compatible with the finding by Sadjadi et al. (1983) who reported that no significant differences between white and blue egg layers were found for their shell quality, shell thickness, albumen weight, yolk weight, or yolk cholesterol content.

\section{CORRELATION ANALYSIS}

Correlation coefficients between egg shell image analysis parameters and egg quality traits for the different five studied categories of egg shell color patterns are presented in Tables 2, 3 and 4.

Evidenced by the results obtained from Table 2 showed that most significant correlation coefficients, whether positive or negative, between red, green and blueegg shell image analysis parameters with the most of the external or internal egg quality traits $(P \leq 0.05$ and $P \leq 0.01)$ were found in white, black spotted, pin dotted egg categories. Which means that it can therefore relied upon as criteria to express the extent of the egg quality traits for these groups of eggs

Generally strong correlations, whether positive or negative, ranging from medium to high were found between image analysis measurements of egg shell ( hue, saturation\%, lightness\% and pigmentation\% ) with some exterior and interior parameters of eggs quality traits for different studied groups (Tables 3 and 4) which can be used in the preparation of other prospective studies, same notes were cited by Aygun (2014) who reported that some egg quality traits vary with the color of the egg shell and the classification of eggs according to egg shell color may be commercially important. These results were in harmony with the findings of Yang et al. (2009) who reported that the color was correlated with shell strength, shell weight and shell thickness, however, it was interconnected with shape index, yolk weight, albumen weight, Haugh unit, and yolk color while Hsiu-Chou and Teng-Kuei, (2010) found that the correlation coefficients between egg shell color and egg shell thickness was 0.37 . Little or there is no previous studies to show connection between image analysis measurements for egg shell and egg quality traits. 
Table 1. Means \pm SE of image analysis measures, external and internal egg quality traits and chemical composition of egg components for the five different categories of eggshell pattern in Japanese quail.

\begin{tabular}{|c|c|c|c|c|c|c|}
\hline \multirow{2}{*}{ Trait } & \multicolumn{6}{|c|}{ Egg groups } \\
\hline & White egg & $\begin{array}{c}\text { Black } \\
\text { spotted }\end{array}$ & Pin dotted & $\begin{array}{l}\text { Sandy } \\
\text { gray }\end{array}$ & Heavily dark & Mean \\
\hline \multicolumn{7}{|c|}{ Image analysis measurements } \\
\hline Red & $171.6 \pm 3.8^{\mathrm{a}}$ & $148.0 \pm 1.0^{b}$ & $135.4 \pm 1.0^{c}$ & $128.0 \pm 1.1^{\mathrm{d}}$ & $127.3 \pm 1.0^{\mathrm{d}}$ & $142.1 \pm 0.8$ \\
\hline Green & $155.3 \pm 4.0^{\mathrm{a}}$ & $122.6 \pm 1.1^{b}$ & $103.3 \pm 1.1^{\mathrm{c}}$ & $104.8 \pm 1.1^{\mathrm{c}}$ & $94.6 \pm 1.1^{\mathrm{d}}$ & $116.1 \pm 0.9$ \\
\hline Blue & $122.0 \pm 3.9^{\mathrm{a}}$ & $82.8 \pm 1.0^{\mathrm{b}}$ & $65.3 \pm 1.1^{\mathrm{d}}$ & $72.4 \pm 1.1^{\mathrm{c}}$ & $56.4 \pm 1.1^{\mathrm{e}}$ & $79.8 \pm 0.9$ \\
\hline Saturation \% & $23.3 \pm 2.0^{d}$ & $29.1 \pm 0.5^{c}$ & $35.1 \pm 0.5^{b}$ & $28.7 \pm 0.5^{c}$ & $38.9 \pm 0.5^{\mathrm{a}}$ & $35.5 \pm 0.2$ \\
\hline Lightness\% & $58.0 \pm 1.3^{\mathrm{a}}$ & $45.1 \pm 0.3^{b}$ & $39.6 \pm 0.3^{c}$ & $39.1 \pm 0.4^{c}$ & $36.0 \pm 0.3^{\mathrm{d}}$ & $31.0 \pm 0.4$ \\
\hline Hue(degree) & $39.0 \pm 1.1^{\mathrm{a}}$ & $37.2 \pm 0.3^{b}$ & $33.0 \pm 0.3^{c}$ & $35.8 \pm 0.3^{b}$ & $32.4 \pm 0.3^{c}$ & $43.6 \pm 0.3$ \\
\hline Pigmentation $\%$ & $6.2 \pm 4.9^{d}$ & $55.5 \pm 1.4^{b}$ & $67.4 \pm 1.3^{\mathrm{a}}$ & $36.6 \pm 1.4^{c}$ & $69.3 \pm 1.3^{\mathrm{a}}$ & $47.0 \pm 1.1$ \\
\hline \multicolumn{7}{|c|}{ External egg quality traits } \\
\hline Egg weight (g) & $10.7 \pm 0.4^{c}$ & $11.2 \pm 0.1^{\mathrm{bc}}$ & $11.8 \pm 0.1^{\mathrm{ab}}$ & $12.4 \pm 0.1^{\mathrm{a}}$ & $11.3 \pm 0.1^{\mathrm{bc}}$ & $11.5 \pm 0.1$ \\
\hline Egg shape index & $78.1 \pm 1.1^{\mathrm{b}}$ & $80.1 \pm 0.3^{\mathrm{a}}$ & $80.6 \pm 0.3^{\mathrm{a}}$ & $81.2 \pm 0.3^{a}$ & $81.1 \pm 0.3^{\mathrm{a}}$ & $80.2 \pm 0.2$ \\
\hline Egg volume $\left(\mathrm{cm}^{3}\right)$ & $9.9 \pm 0.3^{c}$ & $10.3 \pm 0.1^{\mathrm{bc}}$ & $10.8 \pm 0.1^{\mathrm{ab}}$ & $11.4 \pm 0.1^{\mathrm{a}}$ & $10.1 \pm 0.1^{\mathrm{c}}$ & $10.5 \pm 0.0$ \\
\hline $\begin{array}{l}\text { Surface } \\
\text { area }\left(\mathrm{cm}^{2}\right)\end{array}$ & $23.2 \pm 0.5^{c}$ & $23.8 \pm 0.1^{\mathrm{c}}$ & $24.8 \pm 0.1^{\mathrm{ab}}$ & $25.5 \pm 0.1^{\mathrm{a}}$ & $24.0 \pm 0.1^{\mathrm{bc}}$ & $24.3 \pm 0.1$ \\
\hline $\begin{array}{l}\text { USSAW } \\
\left(\mathrm{mg} / \mathrm{cm}^{2}\right)\end{array}$ & $40.7 \pm 1.2^{\mathrm{d}}$ & $43.4 \pm 0.3^{c}$ & $45.4 \pm 0.3^{\mathrm{ab}}$ & $47.0 \pm 0.3^{a}$ & $43.8 \pm 0.3^{b c}$ & $44.1 \pm 0.2$ \\
\hline $\begin{array}{l}\text { Shell percentage } \\
(\%)\end{array}$ & $8.0 \pm 0.4^{c}$ & $8.9 \pm 0.1^{\mathrm{ab}}$ & $8.3 \pm 0.1^{b c}$ & $9.3 \pm 0.1^{a}$ & $8.7 \pm 0.1^{\mathrm{ab}}$ & $8.6 \pm 0.1$ \\
\hline $\begin{array}{l}\text { Shell } \\
\text { thickness(mm) }\end{array}$ & $22.6 \pm 0.4^{b}$ & $22.7 \pm 0.1^{\mathrm{b}}$ & $23.2 \pm 0.1^{b}$ & $24.0 \pm 0.1^{\mathrm{a}}$ & $23.3 \pm 0.1^{\mathrm{b}}$ & $23.2 \pm 0.1$ \\
\hline \multicolumn{7}{|c|}{ Internal egg quality traits } \\
\hline Albumen (\%) & $53.8 \pm 2.4^{\mathrm{a}}$ & $53.2 \pm 0.6^{\mathrm{ab}}$ & $53.7 \pm 0.6^{a}$ & $55.0 \pm 0.7^{a}$ & $49.8 \pm 0.6^{b}$ & $53.1 \pm 0.5$ \\
\hline Albumen index & $11.1 \pm 0.8^{\mathrm{a}}$ & $9.4 \pm 0.2^{b}$ & $10.8 \pm 0.2^{\mathrm{a}}$ & $8.9 \pm 0.2^{b}$ & $10.7 \pm 0.2^{\mathrm{a}}$ & $10.2 \pm 0.1$ \\
\hline Haugh unit & $86.1 \pm 1.0^{c}$ & $86.4 \pm 0.3^{b c}$ & $87.9 \pm 0.3^{\mathrm{ab}}$ & $85.8 \pm 0.3^{c}$ & $88.6 \pm 0.3^{\mathrm{a}}$ & $86.9 \pm 0.2$ \\
\hline IQU & $53.3 \pm 2.6^{\mathrm{b}}$ & $54.9 \pm 0.7^{b}$ & $60.0 \pm 0.7^{\mathrm{a}}$ & $55.6 \pm 0.7^{b}$ & $59.6 \pm 0.7^{\mathrm{a}}$ & $56.7 \pm 0.5$ \\
\hline $\begin{array}{l}\text { Yolk color } \\
\text { (degree) }\end{array}$ & $6.0 \pm 0.4^{\mathrm{a}}$ & $5.4 \pm 0.1^{\mathrm{ab}}$ & $4.6 \pm 0.1^{c}$ & $5.2 \pm 0.1^{\mathrm{abc}}$ & $4.8 \pm 0.1^{\mathrm{bc}}$ & $5.2 \pm 0.1$ \\
\hline $\begin{array}{l}\text { Yolk percentage } \\
(\%)\end{array}$ & $38.0 \pm 2.2^{\mathrm{ab}}$ & $37.8 \pm 0.6^{\mathrm{ab}}$ & $37.9 \pm 0.6^{\mathrm{ab}}$ & $35.5 \pm 0.6^{b}$ & $41.4 \pm 0.6^{\mathrm{a}}$ & $38.1 \pm 0.5$ \\
\hline Yolk index & $40.3 \pm 1.3^{b}$ & $43.2 \pm 0.3^{\mathrm{a}}$ & $45.1 \pm 0.3^{\mathrm{a}}$ & $43.3 \pm 0.3^{\mathrm{a}}$ & $43.6 \pm 0.3^{\mathrm{a}}$ & $43.1 \pm 0.3$ \\
\hline \multicolumn{7}{|c|}{ Chemical composition traits } \\
\hline Moisture (\%) & $71.3 \pm 0.3^{b}$ & $74.6 \pm . \cdot 4^{\mathrm{a}}$ & $73.9 \pm . \cdot 3^{\mathrm{a}}$ & $73.2 \pm . \cdot 4^{a}$ & $74.3 \pm . \cdot 6^{\mathrm{a}}$ & $73.6 \pm . \cdot 1$ \\
\hline Protein (\%) & $13.0 \pm 1.4$ & $13.1 \pm . \cdot 6$ & $13.9 \pm . \cdot 4$ & $14.0 \pm . \cdot 5$ & $13.4 \pm . \cdot 4$ & $13.4 \pm . \cdot 2$ \\
\hline Fat (\%) & $9.7 \pm . \cdot 6^{b}$ & $10.5 \pm . \cdot 2^{\mathrm{a}}$ & $10.6 \pm . \cdot 1^{\mathrm{a}}$ & $11.1 \pm \cdot, \Gamma^{\mathrm{a}}$ & $10.6 \pm . \cdot 2^{\mathrm{a}}$ & $10.8 \pm .+1$ \\
\hline Ash (\%) & $0.8 \pm 1.9$ & $0.9 . \pm 1.2$ & $0.8 \pm . \cdot 8$ & $0.8 \pm 1.0$ & $0.8 \pm 0.8$ & $0.9 \pm . \cdot 5$ \\
\hline Number of eggs & 28 & 184 & 180 & 168 & 184 & 744 \\
\hline
\end{tabular}


Table 2. Correlation coefficients between Red, Green and Blue-eggshell image analysis parameters and egg quality traits for different eggshell pattern groups in Japanese quail.

\begin{tabular}{|c|c|c|c|c|c|c|c|c|c|c|c|c|c|c|c|}
\hline $\begin{array}{l}\text { Image } \\
\text { parameter }\end{array}$ & \multicolumn{5}{|c|}{ Red } & \multicolumn{5}{|c|}{ Green } & \multicolumn{5}{|c|}{ Blue } \\
\hline Egg group & 1 & 2 & 3 & 4 & 5 & 1 & 2 & 3 & 4 & 5 & 1 & 2 & 3 & 4 & 5 \\
\hline ROI & & & & & & & & & & a. & & & & & \\
\hline EW (g) & $-0.59 * *$ & 0.10 & -0.07 & -0.56 & -0.35 & $-0.71^{* *}$ & 0.03 & 0.03 & $-0.70 *$ & -0.30 & $-0.67 * *$ & -0.08 & 0.06 & -0.56 & -0.16 \\
\hline ESI & $-0.54 * *$ & $-0.23 * *$ & $0.39 * *$ & 0.49 & -0.16 & $-0.64 * *$ & -0.08 & $0.24 * *$ & 0.56 & -0.04 & $-0.87 * *$ & 0.01 & $0.17 *$ & 0.35 & 0.01 \\
\hline $\operatorname{EV}\left(\mathrm{cm}^{3}\right)$ & $-0.86 * *$ & 0.05 & -0.09 & -0.54 & -0.26 & $-0.86 * *$ & -0.02 & 0.04 & $-0.70 *$ & -0.25 & $-0.43^{*}$ & -0.12 & 0.07 & -0.56 & -0.14 \\
\hline $\mathrm{SA}\left(\mathrm{cm}^{2}\right)$ & $-0.72 * *$ & 0.10 & -0.08 & -0.56 & -0.35 & $-0.66 * *$ & 0.03 & 0.03 & $-0.70 *$ & -0.29 & $0.61^{* *}$ & -0.08 & 0.06 & -0.55 & -0.16 \\
\hline $\begin{array}{l}\text { USSAW } \\
\left(\mathrm{mg} / \mathrm{cm}^{2}\right)\end{array}$ & $-0.48 * *$ & 0.10 & -0.08 & -0.55 & -0.33 & $-0.39 * *$ & 0.02 & 0.02 & $-0.69 *$ & -0.28 & $0.36 *$ & -0.08 & 0.05 & -0.54 & $\begin{array}{l}-0.15 \\
0.08\end{array}$ \\
\hline SP (\%) & 0.07 & 0.07 & -0.09 & 0.40 & 0.17 & 0.06 & $0.21 * *$ & -0.04 & 0.55 & 0.17 & $0.11 *$ & $0.36 * *$ & 0.09 & 0.41 & \\
\hline ST(mm) & -0.21 & $-0.59 * *$ & $-0.42 * *$ & 0.10 & 0.10 & -0.13 & $-0.34 * *$ & $-0.51 * *$ & 0.16 & -0.01 & $-0.22 * *$ & $-0.16^{*}$ & $-0.48 * *$ & 0.08 & 0.01 \\
\hline AP (\%) & $-0.95 * *$ & $-0.22 * *$ & -0.06 & -0.38 & $0.48 *$ & $-0.98^{* *}$ & $-0.16^{*}$ & -0.09 & $-0.63^{*}$ & 0.24 & $-0.99 * *$ & $-0.16^{*}$ & 0.01 & $-0.73^{*}$ & 0.08 \\
\hline AI & -0.30 & $-0.18^{*}$ & 0.13 & 0.22 & -0.29 & -0.28 & $-0.24 * *$ & $0.18^{*}$ & 0.23 & -0.20 & $-0.27 *$ & $-0.32 * *$ & 0.13 & 0.26 & -0.17 \\
\hline HU & $-0.48^{* *}$ & $-0.38 * *$ & $0.19 *$ & 0.39 & -0.42 & $-0.42 * *$ & $-0.33^{* *}$ & 0.10 & 0.48 & -0.29 & $-0.39 *$ & $-0.35 * *$ & 0.11 & 0.44 & -0.19 \\
\hline IQU & $-0.77 * *$ & $-0.30 * *$ & $0.20 * *$ & 0.53 & -0.36 & $-0.78 * *$ & $-0.23 * *$ & 0.10 & $0.66 *$ & -0.23 & $-0.87 * *$ & $-0.17 *$ & 0.10 & 0.58 & -0.15 \\
\hline YC & $-0.67 * *$ & 0.01 & 0.01 & -0.13 & -0.33 & $-0.87 * *$ & $-0.20 * *$ & -0.01 & -0.09 & -0.35 & $-0.97 * *$ & $-0.35 * *$ & 0.04 & 0.13 & -0.40 \\
\hline YP (\%) & $0.87 * *$ & $0.24 * *$ & 0.08 & 0.29 & -0.29 & $0.90 * *$ & 0.12 & 0.10 & 0.52 & -0.26 & $0.89 * *$ & 0.09 & -0.03 & $0.67 *$ & -0.09 \\
\hline YI & $-0.97 * *$ & -0.10 & $0.37 * *$ & 0.39 & 0.11 & $-0.88^{* *}$ & $-0.16 *$ & 0.11 & 0.48 & -0.08 & $-0.79 * *$ & $-0.26 * *$ & 0.01 & 0.44 & -0.02 \\
\hline
\end{tabular}

*: Significant at $\mathrm{P} \leq 0.05, * *$ : Significant at $\mathrm{P} \leq 0.01,1$ : White egg group, 2: Black spotted egg group, 3: Pin dotted egg group, 4: Sandy gray egg group, 5: Heavily dark egg group, EW: Egg weight (g), ESI: Egg shape index, EV: Egg volume, SA: Surface area $\left(\mathrm{cm}^{2}\right)$, USSAW $\left(\mathrm{mg} / \mathrm{cm}^{2}\right)$ : unit surface shell area weight, SP: Shell percentage, ST: Shell thickness (mm), AP: Albumen percentage, AI: Albumen index, HU: Haugh unit, IQU: Internal quality unit, YC: Yolk color (degree), YP: Yolk percentage, and YI: Yolk index. 
Table 3. Correlation coefficients between Hue, Saturation and lightness -eggshell image analysis parameters and egg quality traits for different eggshell pattern groups in Japanese quail.

\begin{tabular}{|c|c|c|c|c|c|c|c|c|c|c|c|c|c|c|c|}
\hline \multirow{2}{*}{$\begin{array}{l}\text { Image } \\
\text { parameter } \\
\text { Egg group }\end{array}$} & \multicolumn{5}{|c|}{ Hue } & \multicolumn{5}{|c|}{ Saturation\% } & \multicolumn{5}{|c|}{ lightness $\%$} \\
\hline & 1 & 2 & 3 & 4 & 5 & 1 & 2 & 3 & 4 & 5 & 1 & 2 & 3 & 4 & 5 \\
\hline ROI & & 8 & & & $x$ & & & & & 2 & & & & & 20: \\
\hline EW (g) & $0.76 * *$ & -0.01 & 0.07 & $-0.70 *$ & -0.18 & $0.66 * *$ & $0.17 *$ & $-0.25 * *$ & 0.26 & 0.03 & $-0.50 * *$ & -0.01 & 0.10 & -0.55 & -0.34 \\
\hline ESI & $-0.83^{* *}$ & 0.13 & 0.04 & $0.63 *$ & 0.08 & $0.81^{* *}$ & -0.12 & 0.13 & -0.03 & -0.11 & $-0.52 * *$ & -0.10 & $0.24 * *$ & 0.36 & -0.09 \\
\hline $\mathrm{EV}\left(\mathrm{cm}^{3}\right)$ & $-0.86 * *$ & -0.02 & 0.09 & $-0.70 *$ & -0.18 & $0.55^{* *}$ & $0.19 * *$ & $-0.26 * *$ & 0.28 & 0.05 & $-0.96 * *$ & -0.06 & 0.09 & -0.54 & -0.26 \\
\hline $\mathrm{SA}\left(\mathrm{cm}^{2}\right)$ & $0.71 * *$ & -0.01 & 0.06 & $-0.70 *$ & -0.18 & $-0.37 *$ & $0.18^{*}$ & $-0.24 * *$ & 0.26 & 0.03 & $0.50 * *$ & -0.01 & 0.09 & -0.54 & -0.33 \\
\hline $\begin{array}{l}\text { USSAW } \\
\left(\mathrm{mg} / \mathrm{cm}^{2}\right)\end{array}$ & $0.64 * *$ & -0.01 & 0.06 & $-0.69 *$ & -0.18 & -0.06 & $0.18^{*}$ & $-0.24 * *$ & 0.24 & 0.03 & $0.34 *$ & -0.02 & 0.09 & -0.53 & -0.32 \\
\hline SP (\%) & $0.87 * *$ & 0.12 & -0.06 & $0.66^{*}$ & 0.10 & 0.05 & $-0.38 * *$ & -0.13 & -0.18 & -0.02 & $0.53 * *$ & $0.28 * *$ & -0.03 & 0.36 & 0.19 \\
\hline $\mathrm{ST}(\mathrm{mm})$ & $-0.66 * *$ & 0.12 & $-0.40 * *$ & 0.29 & -0.16 & -0.04 & $-0.17 *$ & $0.27 * *$ & 0.12 & 0.05 & $-0.44 * *$ & $-0.39 * *$ & $-0.44 * *$ & -0.04 & 0.08 \\
\hline AP (\%) & $-0.39 * *$ & 0.06 & $-0.17 *$ & $-0.62 *$ & 0.20 & $0.78^{* *}$ & 0.09 & -0.07 & $0.71 *$ & -0.02 & $-0.79 * *$ & $-0.22 * *$ & 0.01 & -0.60 & $0.42 *$ \\
\hline AI & -0.06 & -0.06 & $0.18^{*}$ & 0.21 & -0.05 & 0.27 & $0.30 * *$ & -0.11 & -0.18 & -0.03 & $-0.62 * *$ & $-0.31 * *$ & $0.16^{*}$ & 0.20 & -0.23 \\
\hline HU & 0.13 & 0.01 & -0.04 & 0.48 & -0.12 & 0.10 & $0.17 *$ & -0.01 & -0.35 & -0.10 & $-0.69 * *$ & $-0.41 * *$ & $0.16 *$ & 0.43 & -0.30 \\
\hline IQU & $-0.78 * *$ & 0.01 & -0.05 & $0.67 *$ & -0.08 & $0.82^{* *}$ & 0.02 & 0.02 & -0.41 & -0.11 & $-0.61 * *$ & $-0.26 * *$ & $0.16^{*}$ & 0.57 & -0.23 \\
\hline YC & $-0.79 * *$ & $-0.18 *$ & $-0.16 *$ & -0.10 & -0.14 & $0.72 * *$ & $0.31^{* *}$ & -0.14 & -0.09 & 0.23 & $-0.74 * *$ & $-0.23 * *$ & 0.14 & -0.17 & -0.35 \\
\hline YP (\%) & $0.79 * *$ & -0.11 & $0.19 *$ & 0.48 & -0.21 & $-0.82 * *$ & 0.01 & 0.09 & $-0.71^{*}$ & 0.02 & $0.64 * *$ & $0.18^{*}$ & -0.01 & 0.54 & -0.29 \\
\hline YI & $-0.71 * *$ & -0.06 & $-0.16^{*}$ & 0.48 & -0.34 & $0.80 * *$ & $0.21 * *$ & $0.27 * *$ & -0.35 & 0.08 & $-0.70 * *$ & $-0.22 * *$ & $0.19 * *$ & 0.43 & 0.11 \\
\hline
\end{tabular}

*: Significant at $\mathrm{P} \leq 0.05, * *$ : Significant at $\mathrm{P} \leq 0.01$, ROI: represents images of Region Of Interest taken using a digital camera with 25 mega pixels of resolution and 2 x25 Willumination, 1: White egg group, 2: Black spotted egg group, 3: Pin dotted egg group, 4: Sandy gray egg group, 5: Heavily dark egg group, EW: Egg weight (g), ESI: Egg shape index, EV: Egg volume, SA: Surface area $\left(\mathrm{cm}^{2}\right)$, USSAW $\left(\mathrm{mg} / \mathrm{cm}^{2}\right)$ : unit surface shell area weight, SP: Shell percentage, ST: Shell thickness (mm), AP: Albumen percentage, AI: Albumen index, HU: Haugh unit, IQU: Internal quality unit, YC: Yolk color (degree), YP: Yolk percentage, and YI: Yolk index. 
1106 IMAGE ANALYSIS MEASUREMENTS AND THEIR CORRELATIONS WITH EGG QUALITY TRAITS AND EGG CHEMICAL COMPOSITION OF DIFFERENT EGG SHELL PATTERNS OF JAPANESE QUAIL

Table 4. Correlation coefficients between pigmentation\% -eggshell image analysis parameter and egg quality traits for different eggshell pattern groups in Japanese quail.

\begin{tabular}{|c|c|c|c|c|c|}
\hline Image parameter & \multicolumn{5}{|c|}{ pigmentation\% } \\
\hline Egg group & 1 & 2 & \begin{tabular}{l|l}
3 & \\
\end{tabular} & 4 & 5 \\
\hline Trait & & 8 & & & $\frac{74}{25}$ \\
\hline EW (g) & $-0.71 * *$ & $0.20 * *$ & 0.09 & -0.04 & -0.17 \\
\hline ESI & $-0.64 * *$ & -0.09 & 0.02 & -0.01 & 0.05 \\
\hline$E V\left(\mathrm{~cm}^{3}\right)$ & $-0.87 * *$ & $0.24 * *$ & 0.11 & -0.04 & -0.22 \\
\hline $\mathrm{SA}\left(\mathrm{cm}^{2}\right)$ & $0.66 * *$ & $0.20 * *$ & 0.09 & -0.04 & -0.17 \\
\hline SWUSA & $0.39 * *$ & $0.21 * *$ & 0.09 & -0.04 & -0.16 \\
\hline SP (\%) & 0.06 & -0.11 & -0.11 & -0.06 & $0.45^{*}$ \\
\hline ST(mm) & -0.13 & 0.12 & $-0.28 * *$ & -0.10 & 0.39 \\
\hline AP(\%) & $-0.98 * *$ & -0.11 & 0.07 & -0.19 & 0.25 \\
\hline AIP & -0.28 & $-0.52 * *$ & 0.07 & 0.06 & -0.08 \\
\hline HU & $-0.42 * *$ & $-0.38 * *$ & 0.02 & 0.16 & -0.08 \\
\hline IQU & $0.72 * *$ & $-0.32 * *$ & 0.01 & 0.12 & -0.02 \\
\hline YC & $-0.87 * *$ & -0.06 & $0.37 * *$ & -0.28 & 0.10 \\
\hline YP (\%) & $0.90 * *$ & $0.16 *$ & -0.06 & 0.22 & -0.31 \\
\hline YI & $-0.81 * *$ & 0.01 & $0.23 * *$ & 0.16 & 0.17 \\
\hline
\end{tabular}

*: Significant at $\mathrm{P} \leq 0.05, * *$ : Significant at $\mathrm{P} \leq 0.01,1$ : White egg group, 2: Black spotted egg group, 3: Pin dotted egg group, 4: Sandy gray egg group, 5: Heavily dark egg group, EW: Egg weight (g), ESI: Egg shape index, EV: Egg volume, SA: Surface area $\left(\mathrm{cm}^{2}\right)$, USSAW $\left(\mathrm{mg} / \mathrm{cm}^{2}\right)$ : unit surface shell area weight, SP: Shell percentage, ST: Shell thickness (mm), AP: Albumen percentage, AI: Albumen index, HU: Haugh unit, IQU: Internal quality unit, YC: Yolk color (degree), YP: Yolk percentage, and YI: Yolk index.

\section{CONCLUSION}

Image analysis can be used for classification and comparison between different Japanese quail egg shell pigmentation patterns lines. Sandy gray eggs were better in egg weight, egg shape index, egg volume, surface area, weight of shell per surface area unit, shell percentage and shell thickness, . However no significant differences were observed for chemical composition of egg components between all egg color lines except, white eggs which had significantly the lowest fat percentage compared to the other egg colors this makes it more advantages one in human food consumption as a table egg comparing with the other egg colors.

\section{REFERENCES}

1. Abu Tabeekh, M. A. 2011. Evaluation of some external and internal egg quality traits of quails reared in Basrah city. Bas. J. Vet. Res. 10: (2), p. 78-84. 
2. AOCA. Official Methods of Analyses, $13^{\text {th }}$ Ed. CA, 1990. Association of Official analytical Chemists Washington, DC, USA.

3. Aygun, A. 2014. The relationship between egg shell color and egg quality traits in table eggs. Indian J. Anim. Res., 48 (3) : p. 290-294

4. Duncan, D.B. 1955. Multiple range and multiple F-test. Biometrics, 11: p. 1-42.

5. Duval, C., Cassey, P., Mikšík, I., Reynolds, S. J. and Spencer, K. A. 2012. Condition dependent strategies of egg shell pigmentation: an experimental study of Japanese quail (Coturnix coturnix japonica). Journal of Experimental Biology 216(4): p. 700-708.

6. Farghly M.F.A., KH. M. A. Mahrose and Abou_Kassem, D. E. 2015. Pre and post hatch performance of different Japanese quail egg colors incubated under photostimulation. Asian J. Poult. Sci., 9 (1): p. 19-30.

7. Gosler A.G., J.P. Higham and Reynolds, S.J. 2005. Why are birds' eggs speckled? Ecology Letters, 8: p. 1105-1113.

8. Hassan, H. A., S.S. EL-Nesr, A. M. R. Osman and Arram, G. A. 2014. Ultrastructure of egg shell, egg weight loss and hatching traits of Japanese quail varying in egg shell color and pattern using image analysis.Egypt poult. Sci. $34: 1$, p. $1-17$.

9. Hrncar, E. Hanusova, A. Hanus, J. Bulko. 2014. Effect of genotype on egg quality Characteristics of Japanese quail (Coturnix japonica). Slovak J. Anim. Sci., (47)1: p. 6-11.

10. Hsiu-Chou, L. and Teng-Kuei, W C. 2010. Egg shell pigmentation: a review. J. Chin. Soc. Anim. Sci. 39(2) : p.75-89,

11. Joseph, N. S., N. A. Robinson, R. A. Renema, and. Robinson, F. E. 1999. Shell quality and color variation in broiler breeder eggs. J. Appl. Poult. Res. 8: p70-74.

12. Kondaiah, N., Panda, B. and Singhal, R.A. Internal egg quality measures for quail eggs. 1983. Indian Journal of Animal Sci., 53: p. 1261-1264,

13. Kul S. and Seker I. 2004. Phenotypic correlation between some external and internal egg quality traits in Japanese quail. Int J Poult. Sci. 3 (6): p 400-405.

14. Minvielle, F., J. L. Monvoisin, J. Costa, Frenot, A. 1997. Quail lines selected for egg number based on pure line or crossbred performance. Proceedings of the 12th symposium on Current Problems in Avian Genetics (Aviagen), Pruhonice (Czech Republic). p. 99-103.

15. Mikšík, I., V. Holáň, and Z. Deyl. 1996. Avian egg shell pigments and their variability. Comp. Biochem. Physiol. 113B:607-612.

16. Murakami, A. E., Souza, L. M. G., Sakamoto, M. I., Fernandes, J. I. M. (2008). Using processed feeds for laying quails (Coturnix coturnix japonica). Revista Brasileira de Ciência Avícola, 10: p. 205-208. 
1108 IMAGE ANALYSIS MEASUREMENTS AND THEIR CORRELATIONS WITH EGG QUALITY TRAITS AND EGG CHEMICAL COMPOSITION OF DIFFERENT EGG SHELL PATTERNS OF JAPANESE QUAIL

17. Narahari, D.; Abdul-Mujev, K.; Thangavel, A.;Ramamurty, N. ; Visunathan, S.; Mohan, B.; Murgananda, B. and Sunrararosu, V. (1988). Traits influencing the hatching performance of Japanese quail eggs. Br. Poult. Sci. 29: 101-1: p. 6772.

18. Narushin, V.G. 1992. Calculation of egg geometric traits. Poultry Husbandry, 10: p. 9- 10.

19. Nowaczewski, S., T. Szablewski, R. Cegielska - Radziejewska, Kontecka, H. 2013. Egg morphometry and egg shell quality in ring-necked pheasants kept in cages. Ann. Anim. Sci., 13: p. 531-541.

20. NRC 1994. National Research Council.Nutrient Requirements of Poultry.9th Ed. National Academy of Sciences. Washington, D.C., U

21. Odabaşi, A. Z., R. D. Miles, M. O. Balaban, and K. M. Portier. 2007. Changes in brown egg shell color as hen ages. Poult. Sci. 86:356-363. SA.

22. Oliveira, C. A. F., Ogido, R., Ledoux, D. R., Rottnghaus, G. E., Correa, B., Reis, T. A. and Goncalez, E. 2007. The quality of eggs from Japanese quail, Coturnix japonica, fed rations containing aflatoxin B1 and fumonisin B1. Journal of Poultry Science, 44: p. 29-33.

23. Orhan, H., C. Erensaymn, S., Aktan. 2001. Japon bdlddrcdnlardnda (Coturnix coturnix japonica) farkld yaş gruplardnda yumurta kalite özelliklerinin belirlenmesi. Hayva nsal Üretim Dergisi, vol. 42, 2001, p. 44-49.

24. Paganelli C.V., Olszowska A., Ar A. 1974. The avian egg: surface area, volume, and density. The Condor, 76, 319-325.

25. Sadjadi, M., J. A. Renden, F. H. Benoff, and Harper J. A. 1983. Effects of the blue egg shell allele $(O)$ on egg quality and other economic traits in the chicken. Poult. Sci. 62:p. 1717-1720.

26. SAS User's Guide. 2003. Version 9.1 (TS1M3), SAS Institute, Inc., Carry, NC, USA.

27. Sanz, J.J. and V. García-Navas. 2009. Egg shell pigmentation pattern in relation to breeding performance of blue tits Cyanistescaeruleus. J. Anim. Behav., 78: p.31-41.

28. Sezer, M. and Tekelioglu, O. 2009. Quantification of Japanese quail egg shell color by image analysis. Biological Research 42:p. 99-105.

29. Viscarra, R. R.A. Minasny, B. Roudier, P. and McBratney, A.B. 2006. Colour space models for soil science. 133: p. 320-337

30. Yang, H. M., and Wang, Z. Y. 2009. Study on the relationship between egg shell colors and egg quality as well as shell ultrastructure in Yangzhou chicken. Afr. J. Biotechnol. 8: p. 2898-2902. 


\title{
مقاييس تحليل الصور وارتباطتها بصفات الجودة والتحليل الكيميائى للبيضة لانماط قشرة بيض مختلفة فى السمان اليابانى
}

\author{
محمد حامد عبد الفتاح ، ام هاثم يوسف على محفوظ ، هشام احمد عبداللطيف ، عدام \\ حسن عبدالكريم حسن ، معتز ابراهيم بدوى \\ معهُ بحوث الانتاج الحيوانى مركز البحوث الزراعية الدقى الجيزة
}

اجريت هذه الدراسة للتعرف على تأثثر تباين لون ونمط فشرة بيض السمان اليابانى على

مقاييس تحليل الصورة لقشرة البيض، صفات جودة البيضة و التركيب الكيمبائى للمكونات الداخلية

للبيض ومدى ونوعية ارتباط بين مقاييس تحليل الصورة لقشرة البيضه مع صفات جودة البيضة

و التركيب الكيمبائى لمكوناتها. تم قياس مقاييس تحليل الصورة وصفات الجودة البيضة الخارجية

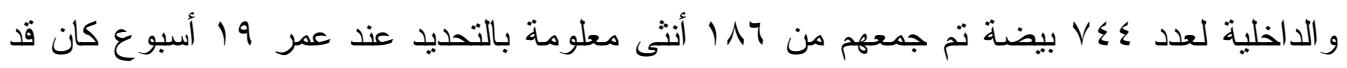

سبق تصنيفهم الى مجمو عات مميزه وفقا للون ونمط قتشرة البيضة إلى خمس مجمو عات هي:

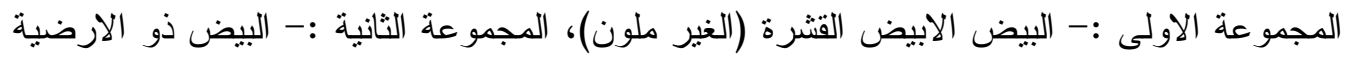

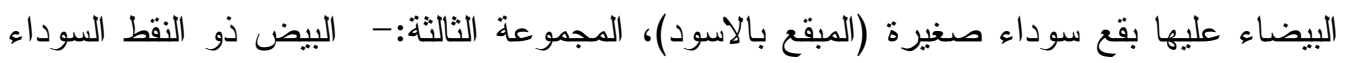

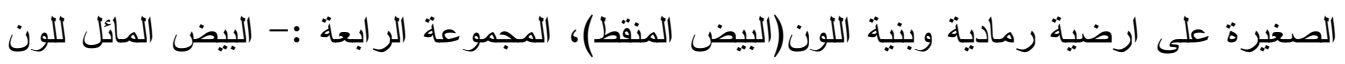

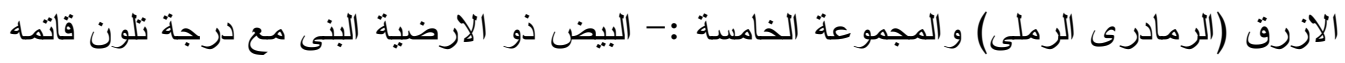

$$
\text { وخلصت النتى القانم) }
$$

يمكن استخدام برامج تحليل الصورة فى التصنيف والمقارنة بين نمازج وأنماط بيض مختلفة فى لون وشكل القشرة فى السمان اليابانى ودراسة الاختلافات فيما بينهم كما انه وجدت ارتباطات كبيرة، سو اء إيجابية أو سلبية بين قياسات تحليل الصور لأنماط قشرة البيضة وبعض ولئل صفات جودة البيضة لمختلف المجموعات المدروسة والتي يمكن استخدامها في الدراسات المستقبلية. تميز البيض الرمادى رملى القترة فى كل صفات جودة البيضة الخارجية وبعض بله

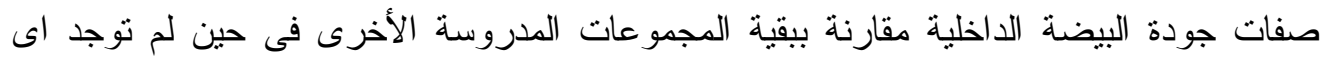
اختلافات معنوية للتركيب الكيميائى لمكونات البيضة الداخلية بين كل مجموعات أنماط فشرة

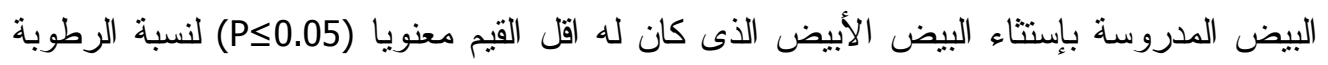

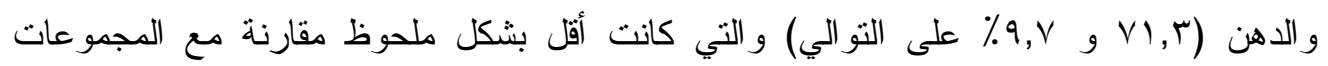

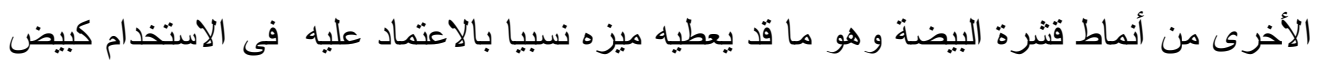
مائدة للاستهلاك كغذاء للإنسان مقارنة بالمجموعات الأخرى من بيض السمان ذو القشرة الملونة. 
1110 IMAGE ANALYSIS MEASUREMENTS AND THEIR CORRELATIONS WITH EGG QUALITY TRAITS AND EGG CHEMICAL COMPOSITION OF DIFFERENT EGG SHELL PATTERNS OF JAPANESE QUAIL 